\title{
Impacts of greenhouse warming on water temperature and water quality in the southern United States
}

\author{
Ellen J. Cooter ${ }^{1, *}$, William S. Cooter ${ }^{2}$ \\ ${ }^{1}$ Oklahoma Climatological Survey, 710 Asp, Suite 8, Norman, Oklahoma 73019, USA \\ ${ }^{2}$ Oklahoma Conservation Commission, 2800 N. Lincoln Blvd., Suite 160, Oklahoma City, Oklahoma 73105, USA
}

\begin{abstract}
The implications of possible increases in carbon dioxide and other greenhouse gases on water resources have attracted increasing attention. Well-established techniques have been used to relate air temperature scenarios produced by GISS, GFDL and OSU global climate models to surface water temperatures and, subsequently, to water quality through a waste load allocation model for streams across the southern United States. There is a consensus among the 3 GCM scenarios studied that surface water temperature increases of up to $7^{\circ} \mathrm{C}$ can be expected. Results of the application of a Streeter-Phelps waste load allocation model indicate that even though existing advanced treatment technology would be sufficient to maintain desirable levels of instream dissolved oxygen under elevated water temperature conditions, the use of such technology would be necessary on a much wider scale than at present. The use of extensive riparian vegetative shading was considered as a supplement to advanced water treatment technology. Results show that under 2 of the 3 climate change scenarios and projected patterns of forest migration, shading could appreciably offset the greenhouse-induced water temperature increases east of longitude $97^{\circ} \mathrm{W}$. If present maximum levels of natural riparian assemblages were maintained but no species migration were to take place, water temperatures could still rise in some areas as much as $7^{\circ} \mathrm{C}$. If other environmental or anthropogenic stresses were to result in a major decrease in vegetative cover, such water temperature increases could easily be exceeded.
\end{abstract}

\section{INTRODUCTION AND BACKGROUND}

In recent years, the implications of global warming on water resources have attracted increasing attention. General overviews may be found in the 'EPA Journal' (United States Environmental Protection Agency [US EPA] 1989), in Jacoby (1989) and in Waggoner (1990), the latter report outlining the basic viewpoints of the American Academy for the Advancement of Science. In the main, these studies are of a broad, qualitative nature and emphasize the economic and social implications of water supply issues.

Water supply considerations are critical to many aspects of greenhouse effect studies dealing with water quality issues. Miller \& Brock (1989) explored connections between water quantity and water quality for

\footnotetext{
- NOAAVARL on assignment to the Atmospheric Research and Exposure Assessment Laboratory, US Environmental Protection Agency, M.D. 80, Research Triangle Park, North Carolina 27711, USA
}

Tennessee Valley Authority reservoir systems. Cooter (1990) modeled greenhouse-induced changes in runoff-related pesticide transport patterns for corngrowing areas of the southern United States. These studies, as well as research by Grotch (1988), highlight the challenges of isolating clear-cut regional changes when comparing present, baseline temperature and precipitation patterns to hypothesized conditions associated with greenhouse warming effects.

Regional patterns of change in precipitation are particularly difficult to establish. In comparison, determining regional patterns of temperature-dependent effects on water quality is far more straightforward. Wellestablished techniques are available to relate air temperatures to water temperatures, and water temperatures are a key variable in many available water quality models, especially in so-called waste load allocation models for streams (Zison et al. 1978, O'Connor 1984).

For smaller stream systems, water temperatures and shading from riparian vegetation are strongly corre- 
lated (US EPA 1973). These shading effects can be predicted and used as inputs for waste load allocation models. Since waste load allocation modeling usually focuses on typical summer low-flow, high-temperature conditions, this minimizes perturbations from precipitation-dependent variability.

Focussing on summer critical conditions helps highlight changes tied to potential greenhouse effects on surface air temperature regimes. Attention to the impacts of different degrees of stream shading also focuses attention on a policy variable subject to human control. Temperature-dependent waste load allocation models can predict changes in such important water quality features as in-stream dissolved oxygen levels. Much of the thrust of such public laws as the US Clean Water Act aims at controlling the effluents of point source discharges, to avoid depletion of dissolved oxygen levels deleterious to fish or other aquatic life. While traditional approaches for controlling in-stream dissolved oxygen levels have stressed the technologybased treatment of waste waters, attention is now turning to innovative uses of wetlands and riparian vegetation to achieve comparable water quality benefits (Wetland Training Institute 1989).

As will be seen, the preservation, or restoration, of timber cover in riparian corridors could become an important policy option under future scenarios of greenhouse warming. The estimated shading benefits would help damp-out potential increases in water temperatures. Reducing stream temperatures reduces oxygen demands from discharged effluents, thus serving to protect water quality conditions using available technological measures for wastewater treatment.

In reaching these conclusions, data for current climatological conditions were combined with predictions from general circulation models (GCMs), to derive regional estimates of high summer (July) air temperatures. Results of 3 such models were used to establish a range of possible water temperature scenarios for the southern United States (Alabama, Arkansas, Florida, Georgia, Louisiana, Mississippi,
North Carolina, Oklahoma, Tennessee, Texas, South Carolina and Virginia). Although each GCM sets out to simulate similar physical processes, the manner and scale in time and space by which these models operate vary widely. As a result, the estimation of air temperature changes associated with a doubling of $\mathrm{CO}_{2}$ in the atmosphere varies as well. Yet, throughout the southern United States, there is general agreement among the 3 models on the direction of temperature change. Finally, regional estimates of July air temperatures were used to determine water temperature and dissolved oxygen as well as the implications of these results for water treatment facilities.

\section{METHODOLOGY FOR USE OF GCM OUTPUTS}

This study considered outputs from 3 widely used GCM models. The models are: the GISS model from the Goddard Institute of Space Studies (Hansen et al. 1984); the GFDL model from the Geophysical Fluid Dynamics Laboratory (Manabe \& Wetherald 1987); and the OSU model from Oregon State University (Schlesinger \& Zhao 1989). Table 1 summarizes the major features of these models. From each of these models, data are available from a 'base' $10 \mathrm{yr}$ steadystate run assuming current levels of atmospheric $\mathrm{CO}_{2}$ and a $10 \mathrm{yr}$ steady-state run assuming a doubling of atmospheric $\mathrm{CO}_{2}$. For both the 'base' and future runs, a variety of estimated climatological statistics pertinent to this study are available (e.g. mean monthly air temperatures, humidity, surface incident solar radiation, total cloud cover, and average surface wind speeds).

The primary use of such model-generated values is to provide scenarios with a significant degree of spatial climate change detail. It is not the aim of this study to assess the accuracy of such model scenarios. A major criterion for such assessments would be the degree to which the 'base' (or 'current' condition) simulations correspond to climatological averages using actual historical data. Grotch (1988) offers a comparison of the

Table 1. Select GCM model attributes

\begin{tabular}{|c|c|c|c|}
\hline & GISS & GFDL & OSU \\
\hline Model resolution (lat. $\times$ long.) & $7.83^{\circ} \times 10^{\circ}$ & $4.44^{\circ} \times 7.5^{\circ}$ & $4.0^{\circ} \times 5.0^{\circ}$ \\
\hline Available variables & 19 & 19 & 9 \\
\hline Solar constant ${ }^{a}$ & $1367 \mathrm{Wm}^{-2}$ & $1443.7 \mathrm{Wm}^{-2}$ & $1354 \mathrm{Wm}^{-2}$ \\
\hline Doubled $\mathrm{CO}_{2}$ concentration & $630 \mathrm{ppm}$ & $600 \mathrm{ppm}$ & $652 \mathrm{ppm}$ \\
\hline Diurnal cycle & Yes & No & No \\
\hline Annual average planetary albedo & $30 \%$ & $30 \%$ & $30 \%$ \\
\hline $\begin{array}{l}\text { Global average temperature } \\
\text { change under double atmospheric } \mathrm{CO}_{2}\end{array}$ & $+4.2^{\circ} \mathrm{C}$ & $+4.0^{\circ} \mathrm{C}$ & $+2.8^{\circ} \mathrm{C}$ \\
\hline
\end{tabular}



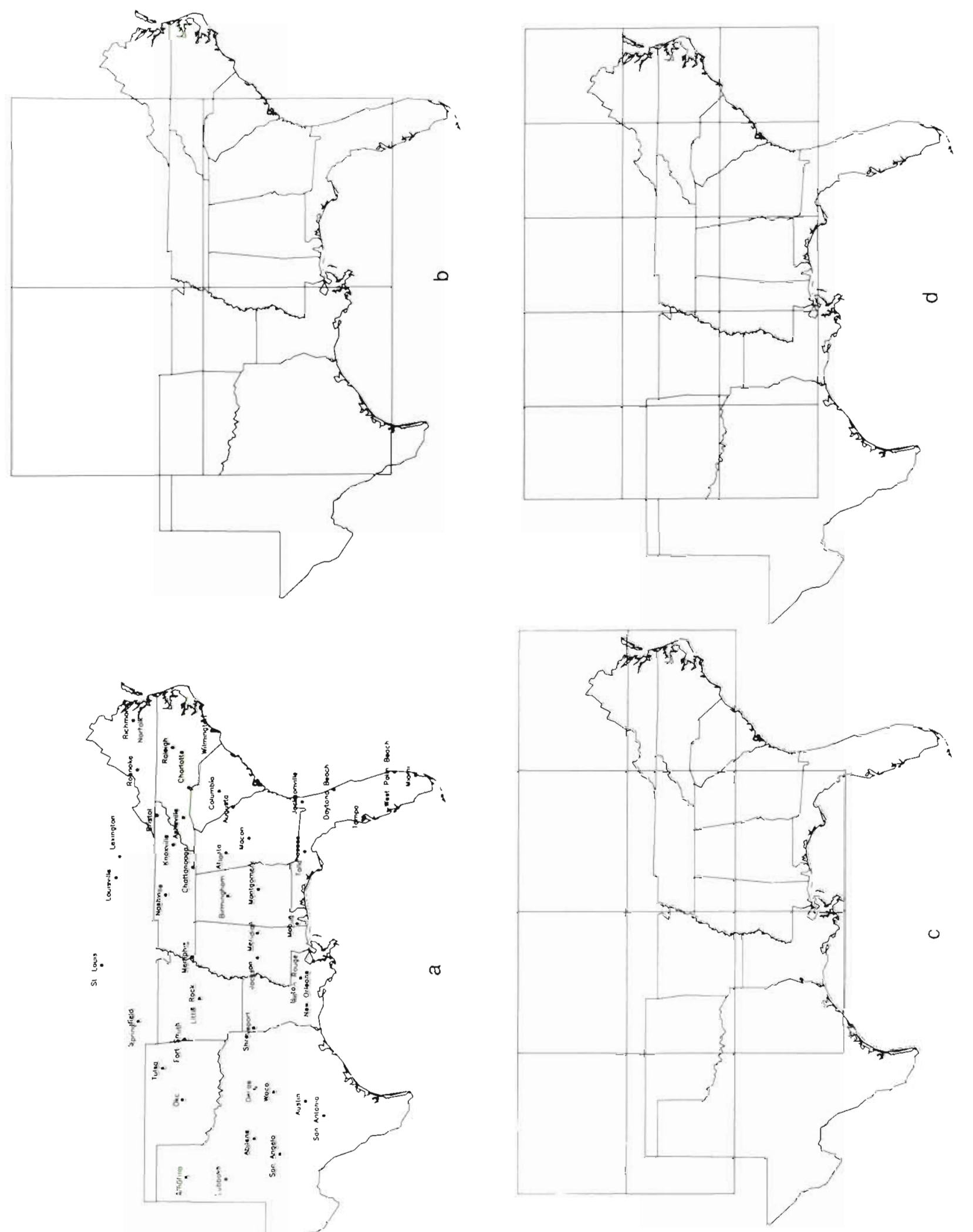

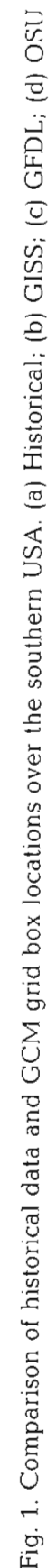

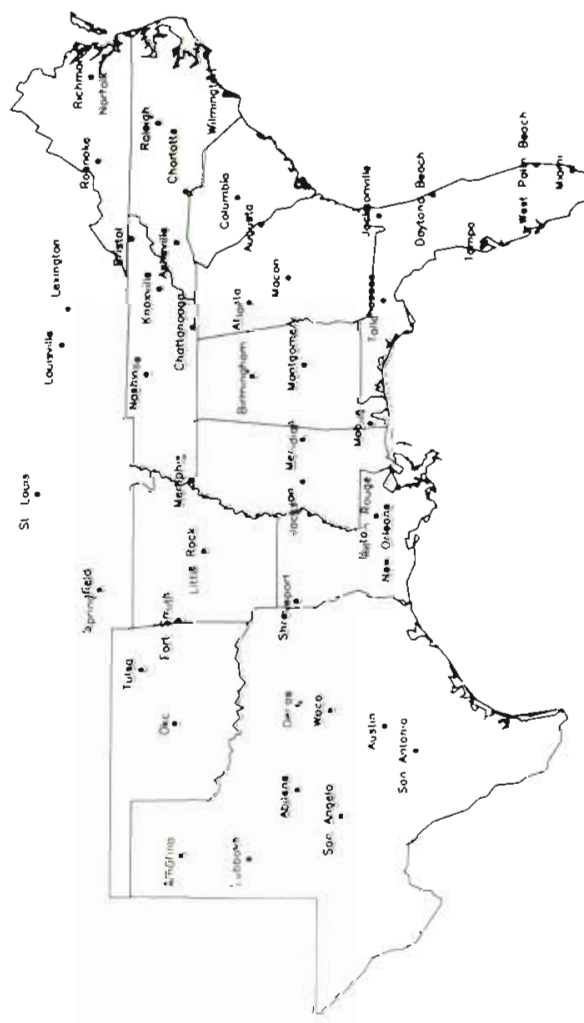

$\infty$ 


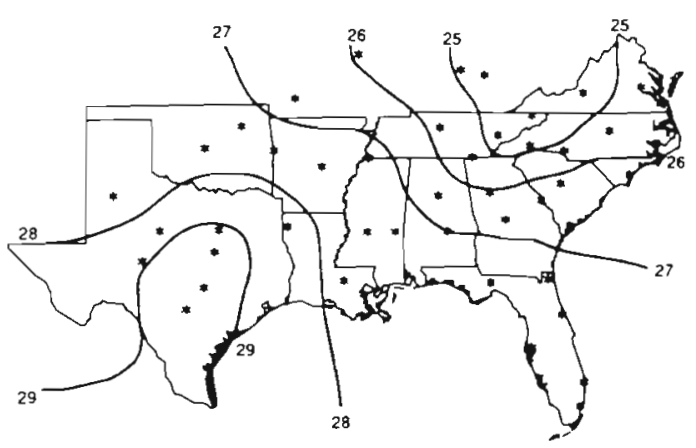

a

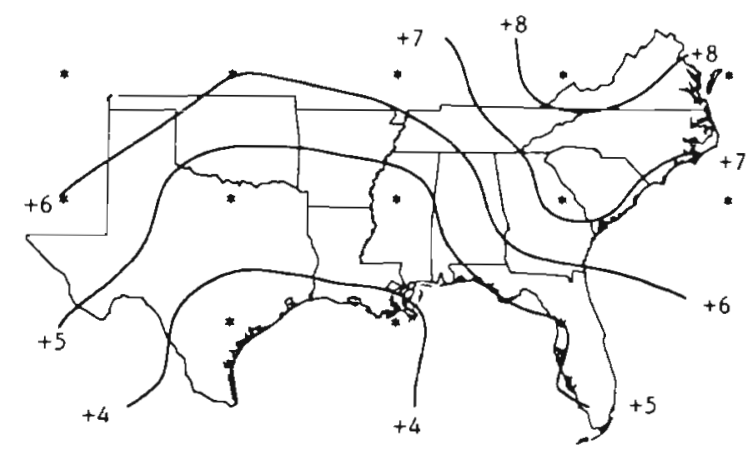

C
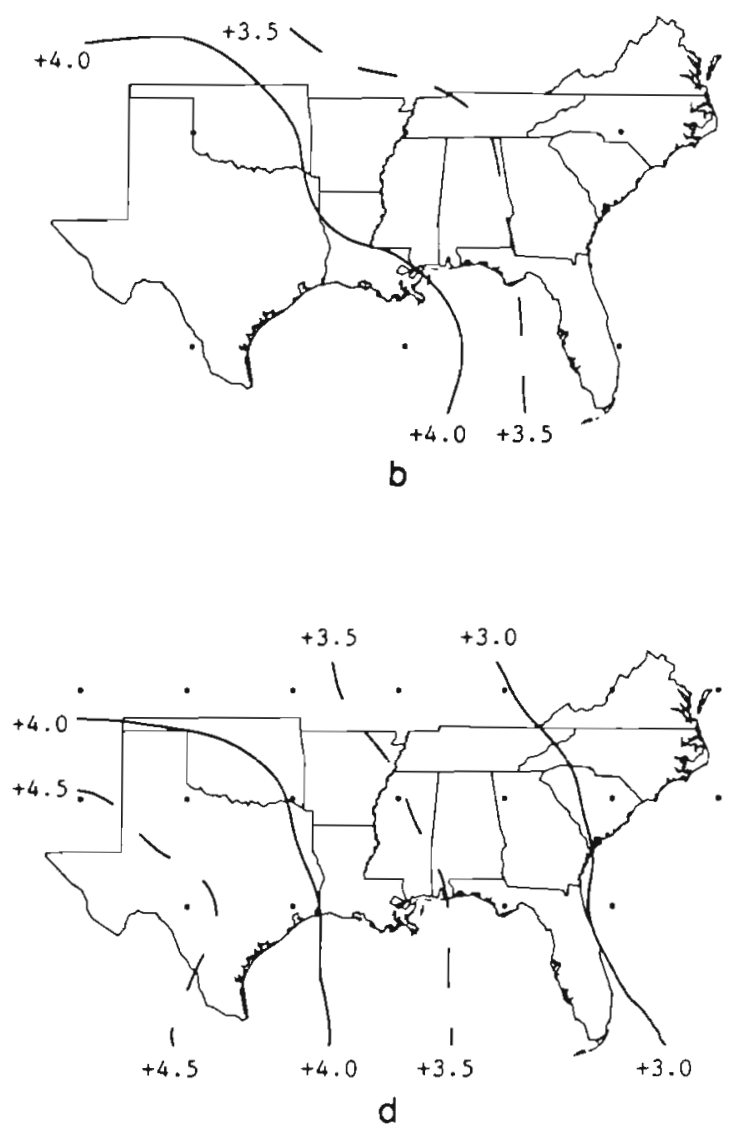

Fig. 2. July air temperatures (30 yr mean) and changes from mean July GCM base air temperatures resulting from doubled atmospheric $\mathrm{CO}_{2}\left({ }^{\circ} \mathrm{C}\right.$ ). (a) Historical base; (b) GISS; (c) GFDL; (d) OSU

temperature and precipitation estimates of a variety of GCMs (including the GISS, GFDL, and OSU models). For small spatial units and for time periods shorter than seasonal averages, the GCMs cannot now simulate historical conditions with great accuracy. Still, the differences between model 'base' and model 'future' conditions provide the best tool available for predicting a range of potential changes stemming from greenhouse warming.

Historical weather sites used for this analysis and their proximity to GCM model grid boxes are given in Fig. 1. The historical data (NOAA 1978) consist of longterm mean July conditions (30 yr mean values for temperature, wind speed, humidity and cloud cover) at First Order Meteorological Stations. Material in Knapp et al. (1980) gives mean July insolation data.

Fig. 2 shows maps of historical mean July air temperatures and changes from GCM base temperature conditions for the study area. These maps display the direction, magnitude, agreement and spatial distribution of GCM results. The contoured values in Fig. $2 \mathrm{a}$ use gridded climatological point values. Grid-point temperature changes in Fig. 2c, d show consistent increases throughout the study area. The increases range from 3.5 to $10^{\circ} \mathrm{C}$. There is general agreement between the OSU and GISS scenarios in terms of magnitude and geographic location of temperature increase. GFDL changes are more zonal in nature, the largest increase being roughly twice that of the other 2 models. The area of greatest temperature increase for the GISS and OSU scenarios is in the southwestern quadrant of the study area. The GFDL scenario places the largest surface temperature increases in the northeastern quadrant.

\section{RELATING GREENHOUSE WARMING TO CHANGES IN WATER QUALITY}

While water temperature changes in themselves can impact instream conditions and influence the types of aquatic life present, these impacts will be greatly magnified for streams receiving any significant inputs of oxygen-demanding substances, e.g. from point source dischargers. Even for water temperatures around 
$40^{\circ} \mathrm{C}$, natural streams with low levels of organic loadings usually maintain average diurnal dissolved oxygen levels above $6 \mathrm{mg} \mathrm{l}^{-1}$ (American Public Health Association 1985). Dissolved oxygen levels at or above $5 \mathrm{mg} \mathrm{l}^{-1}$ are commonly felt to be desirable to support an ecologically healthy population of fish (US EPA 1976. 1986).

Where point source discharges introduce organic material or ammonia, metabolism by in-stream microorganisms will lower oxygen levels until biochemical transformations deplete the concentrations of the pollutants. A major goal of the EPA's permitting programs is to require dischargers to treat their waste waters adequately so that this in-stream self-purification process will not result in dissolved oxygen levels below acceptable levels (typically $5 \mathrm{mg} \mathrm{l}^{-1}$ ). Permits are set up using modeling techniques similar to those introduced below that estimate the required levels of treatment necessary under critical high summer water temperature and low flow conditions (Leo et al. 1984). If greenhouse effects should lead to critical condition water temperature increases, then the picture would change. Increased water temperatures would raise microorganism metabolism rates. Over a certain length of the stream, dissolved oxygen levels would decline.

In the discussion that follows, the GCM outputs introduced in the previous section provided the basis for estimating increases in water temperatures. Mean July air temperatures formed the basis for estimates of the magnitude of potential water quality problems. Although information about changes in extreme temperature conditions under greenhouse warming are not yet available from GCMs, the estimation of climate extremes and variability continues to be an active research field (Mearns et al. 1984, Katz \& Brown 1989). While the physics involved is well established, one variable in particular is crucial: total solar radiation reaching the water surface. The estimation of this component hinges on the degree to which riparian vegetation intercepts incoming short-wave solar radiation. While this introduces some complications in making realistic estimates, these shading features are very important. Ignoring shading entirely leads to equilibrium water temperature estimates that are unrealistically high. Without some degree of shading, any streams receiving appreciable loadings of oxygen-demanding substances will show severe water quality degradation.

Eq. (1), based on Edinger \& Geyer (1965), gives daily average July equilibrium surface water temperatures:

$$
\begin{gathered}
E=\left[\frac{\left(0.8889-0.0278 \times E^{\prime}\right)}{12.95 \times K}\right]+\left[\frac{1799 \times H_{r}}{K}\right]+ \\
{\left[\frac{(K-1.2123)}{K(0.26+B)}\right]\left[e_{a}-C(B)+\left(0.1445 \times T_{a}\right)-8.32\right]}
\end{gathered}
$$

where $\mathrm{E}=$ equilibrium temperature $\left({ }^{\circ} \mathrm{C}\right) ; \mathrm{E}^{\prime}=$ equilibrium temperature at previous time step $\left({ }^{\circ} \mathrm{C}\right) ; \mathrm{H}_{\mathrm{r}}=$ net incoming short- and longwave radiation $\left(\mathrm{KCal} \mathrm{m}^{-2} \mathrm{~d}^{-1}\right)$; $\mathrm{T}_{\mathrm{a}}=$ ambient air temperature $\left({ }^{\circ} \mathrm{C}\right) ; e_{a}=$ water vapor pressure of ambient air at air temperature $\mathrm{T}_{\mathrm{a}}(\mathrm{mm} \mathrm{Hg})$; $\mathrm{B}=$ proportionality constant $\left(\mathrm{mm} \mathrm{Hg}{ }^{\circ} \mathrm{C}^{-1}\right)^{*} ; \mathrm{C}(\mathrm{B})=$ value dependent on $\mathrm{B}(\mathrm{mm} \mathrm{Hg})_{i} \mathrm{~K}=$ thermal exchange coefficient (Kcal m $\mathrm{m}^{-2} \mathrm{~d}^{-1}{ }^{\circ} \mathrm{C}^{-1}$ ).

Eq. (1) was applied at each station location as described in Mills et al. (1982) using historical values of ambient air temperature, solar radiation, ambient water vapor, wind speed, cloud cover and surface pressure. Table 2 summarizes information on typical native riparian tree species and average heights for the study area (Oklahoma State Department of Agriculture 1981). Fig. 3 gives estimates of the stream width shaded by this bank coverage for the most simple case of a north-south oriented stream. The effect of vegetative shading for this figure is simulated by multiplying the maximum average incoming solar radiation at a location by a shading coefficient. The shading coefficient represents the proportion of daylight hours direct solar radiation reaches the water surface assuming uniformly dense foliage (Eq. 2).

$$
S=\left(A_{\max } / 90^{\circ}\right) \times 100
$$

where $\mathrm{S}=$ shade coefficient (percentage); and $\mathrm{A}_{\max }=$ maximum angle from a horizontal line of sight to the sun for which a given stream width is completely shaded by a given vegetative height (degrees).

For the purposes of this study, a constant stream width of $15 \mathrm{~m}$ was assumed (since streams of this size could potentially enjoy substantial shading from tree species common in the region). Applying this stream width together with information from Table 2 and Eqs. (1) and (2) under historical climate conditions yields contours of estimated surface water temperatures that agree reasonably well with recorded observations (Geraghty et al. 1973).

Next, Eq. (1) was applied to the GCM base and future climate scenarios. Since some GCMs lack estimates for surface pressure, base values were obtained from the closest National Weather Service observation station to each grid point. It is initially assumed that neither station pressure nor vegetative cover (shading coefficient) changed significantly between the base and doubled atmospheric $\mathrm{CO}_{2}$ scenarios. Fig. 4 contains the contoured comparison data for the historical base and GCM results.

\footnotetext{
- British unit nomogram values in Edinger \& Geyer (1965) must be converted to metric units before being used in Eq. (1)
} 
Table 2. Representative riparian species of the southeastern USA

\begin{tabular}{|c|c|c|c|}
\hline Location & $\begin{array}{l}\text { Mature } \\
\text { height }\end{array}$ & Representative species & $\begin{array}{l}\% \text { Shading of } \\
15 \mathrm{~m} \text { stream }\end{array}$ \\
\hline West of $97^{\circ} \mathrm{W}$ longitude & $7 \mathrm{~m}$ & $\begin{array}{l}\text { Celtis reticulata (netleaf hackberry) } \\
\text { Cephalanthus occidentalis (buttorbush) } \\
\text { Fraxinus pennsylvanica (green ash) } \\
\text { Sapindus drummondii (western soapberry) }\end{array}$ & $28 \%$ \\
\hline $\begin{array}{l}\text { East of } 97^{\circ} \mathrm{W} \text { longitude } \\
\text { North of } 34^{\circ} \mathrm{N} \text { latitude }\end{array}$ & $18 \mathrm{~m}$ & $\begin{array}{l}\text { Carya cordiformis (bitternut hickory) } \\
\text { Carya glabra (pignut hickory) } \\
\text { Quercus alba (white oak) } \\
\text { Quercus macrocarpa (bur oak) } \\
\text { Quercus rubra (northern red oak) }\end{array}$ & $62 \%$ \\
\hline $\begin{array}{l}\text { East of } 97^{\circ} \mathrm{W} \text { longitude } \\
\text { South of } 34^{\circ} \mathrm{N} \text { latitude }\end{array}$ & $24 \mathrm{~m}$ & $\begin{array}{l}\text { Celtis laevigata (hackberry) } \\
\text { Pinus glabra (spruce pine) } \\
\text { Quercus falcata (southern red oak) } \\
\text { Quercus laurifolia (swamp laurel oak) } \\
\text { Quercus michauxii (swamp chestnut oak) } \\
\text { Quercus nigra (water oak) } \\
\text { Taxodium spp. (cypresses) }\end{array}$ & $84 \%$ \\
\hline
\end{tabular}

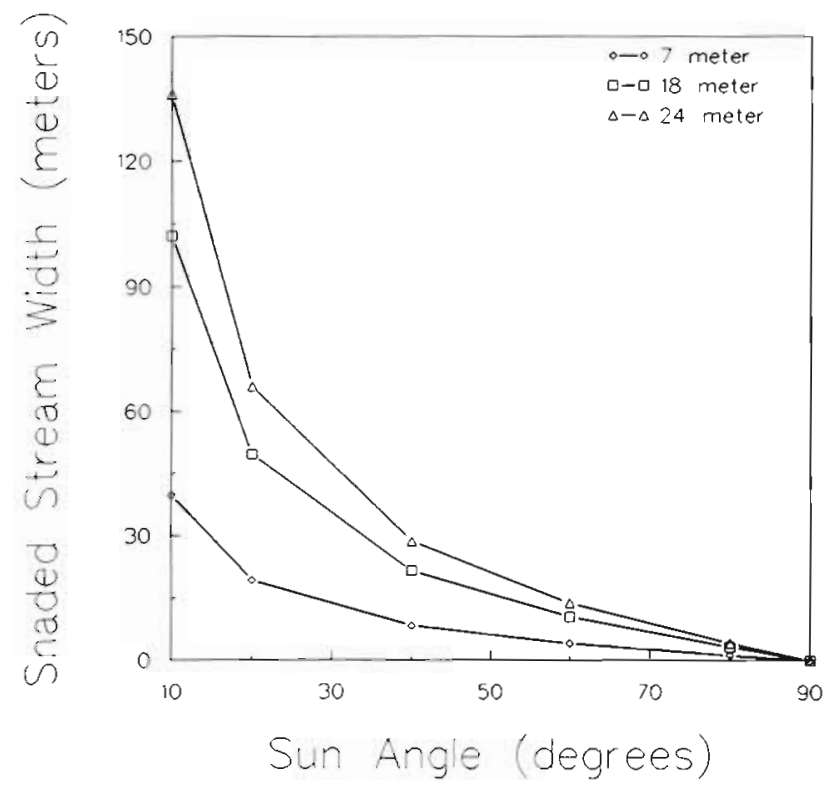

Fig. 3. Computed relationship between riparian height and shaded stream width

The 3 climate change scenarios agree reasonably well on the general magnitude of changes in water temperatures. Predicted increases relative to the base case range from 1 to $7^{\circ} \mathrm{C}$. There is significant disagreement on the location of maximum water temperature increases. The GISS model places the maxima in the far northeastern and southwestern corners of the study area. The GFDL scenario also places the maxima in the northeastern quadrant. The OSU scenario places an area of maximum increase over the Mississippi River. Two major considerations account for these differ- ences. First, there are significant differences among the scenarios in grid-size and computational design (Table 1. Fig. 1). Second, the environmental conditions that are input to Eq. (1) - i.e. radiation, cloud cover, humidity, wind speed and air temperature - vary among the scenarios. Table 3 summarizes these scenario features.

Fig. 5 shows the findings from a sensitivity analysis performed on Eq. (1) to establish the source of differing GCM results. As can be seen, increases in shading and surface wind speed result in decreased water temperatures. Increases in humidity, cloud cover, shortwave radiation and air temperature all contribute to increased surface water temperatures.

The GISS and OSU models appear to be equally sensitive to the effects of doubled atmospheric $\mathrm{CO}_{2}$ for all the environmental parameters listed in Table 3 . The GFDL scenario predicts not only greater air temperature increases (Fig. 2) but also larger increases in all the other variables. Since the GFDL range of water temperature increases is similar to that of the other 2 scenarios, increases in wind speed must counteract the warming effects.

GISS scenario maximum temperatures in the southwest and northeast quadrants appear to result from increased cloud cover and decreased wind speeds. The GFDL scenario suggests increased humidity and large increases in total radiation as sources of temperature increases in the northeast. The OSU model differs from the others in the mid-south by decreased wind speeds. In summary, there is consensus among the GCM scenarios that a doubling in atmospheric $\mathrm{CO}_{2}$ would increase surface water temperatures by 1 to $7^{\circ} \mathrm{C}$ in the southern United States. The location of greatest increase within this region, however, is uncertain. 


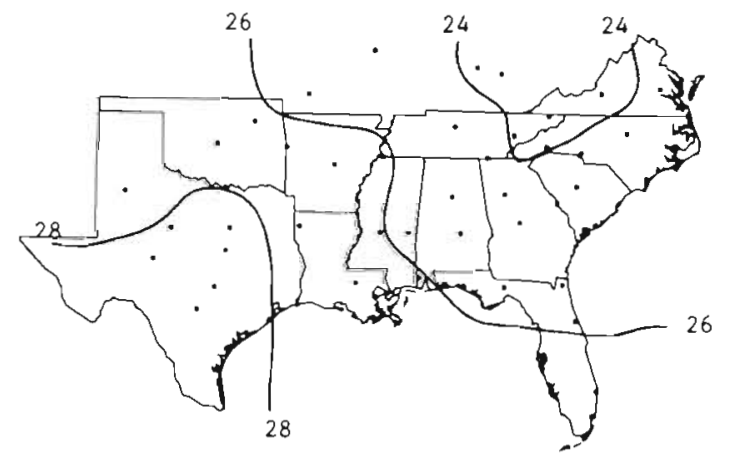

a

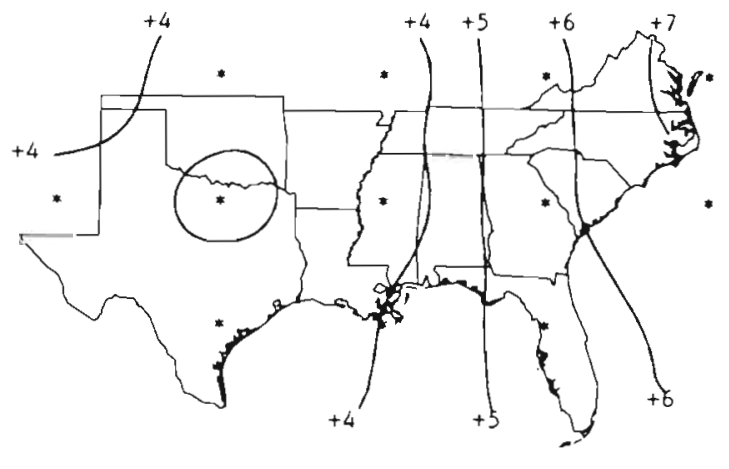

C

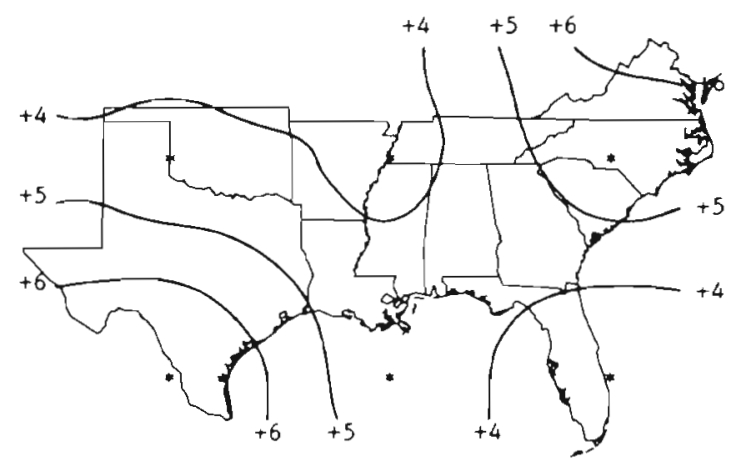

b

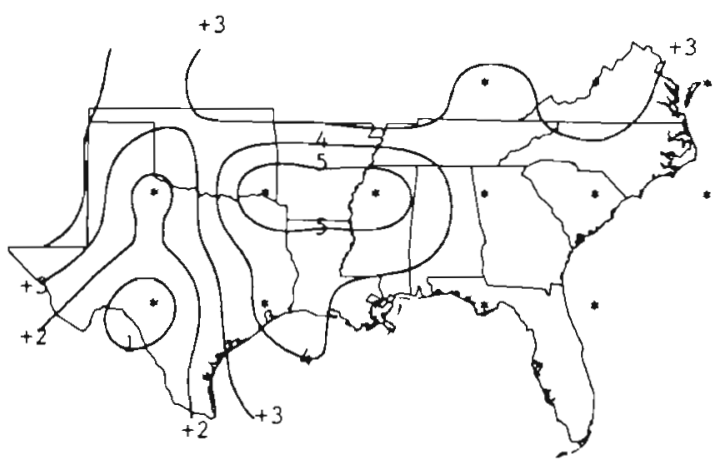

d

Fig. 4. Historical mean July equilibrium surface water temperatures and changes from computed GCM base water temperatures resulting from doubled atmospheric $\mathrm{CO}_{2}\left({ }^{\circ} \mathrm{C}\right.$ ). (a) Historical base; (b) GISS; (c) GFDL; (d) OSU

The next step is to relate computed water temperatures to water quality. The level of dissolved oxygen (DO) is a common measure of water quality. The DO level is usually expressed in terms of the amount of the deficit in concentration below the saturation concentration. A generalized Streeter-Phelps waste load model (as in O'Connor 1984) provides dissolved oxygen estimates:

$$
\begin{aligned}
D(x)= & D_{o} e^{-K_{a}(x / u)} \\
& +\frac{\left(K_{d} L_{o}\right)}{\left(K_{a}-K_{d}\right)}\left[e^{-K_{d}(x / u)}-e^{-K_{a}(x / u)}\right] \\
& +\frac{\left(K_{n} N_{o}\right)}{\left(K_{a}-K_{d}\right)}\left[e^{-K_{n}(x / u)}-e^{-K_{a}(x / u)}\right]
\end{aligned}
$$

where $\mathrm{D}(\mathrm{x})$ = stream dissolved oxygen deficit below saturation ( $\mathrm{mg} \mathrm{l}^{-1}$ ) at distance $\mathrm{x}$ downstream with velocity ( $\mathrm{km} \mathrm{d}^{-1}$ ). Eq. (3a) governs stream reaeration, with $\mathrm{K}_{\bar{a}}=$ reaeration coefficient $\left(\mathrm{d}^{-1}\right)$ corrected for instream-temperature; $D_{0}=$ initial dissolved oxygen deficit (mg $\mathrm{l}^{-1}$ ). Eq. (3b) governs carbonaceous biochemical oxygen demand (CBOD), with $\mathrm{K}_{\mathrm{d}}=$ carbonaceous deoxygenation coefficient corrected for instream temperature $\left(\mathrm{d}^{-1}\right) ; \mathrm{L}_{\mathrm{o}}=$ initial in-stream CBOD (mg $\mathrm{l}^{-1}$ ). Eq. (3c) governs nitrogenous biochemical oxygen demand (NBOD), with $K_{n}=$ nitrogenous deoxygenation coefficient corrected for in-stream temperature $\left(\mathrm{d}^{-1}\right) ; \mathrm{N}_{0}=$ initial in-stream NBOD $\left(\mathrm{mg} \mathrm{l}^{-1}\right)$.

Such a model predicts impacts on streams from oxygen-demanding discharges (e.g. from municipal sewage treatment plants). These modeling techniques provide a screening tool in point source permit decisions by the EPA and individual states. The predictive accuracy of such 'desk-top' models is generally considered adequate for actual permit decisions involving smaller municipal dischargers (e.g so-called 'minor' dischargers of fewer than $10 \mathrm{MGD}$ [million gallons $\mathrm{d}^{-1}$ ]). For 'major' dischargers, more sophisticated models are usually employed (Zison et al. 1978, Leo et al. 1984). For the types of smaller streams (and 'minor' dischargers) that are the primary focus of this study, however, the desk-top wasteload allocation model form is adequate. Table 4 contains the model input values assumed for 'typical' low-flow conditions in the southern United States. A standard Arrhenius correction relationship (Zison et al. 1978) provides adjustments to model rate coefficients for a range of in-stream diurnal average temperatures drawn from the potential water temperature changes in Fig. 4. 
Table 3. Comparison of base and doubled $\mathrm{CO}_{2} \mathrm{GCM}$ scenarios

\begin{tabular}{|c|c|c|c|}
\hline & GISS & GFDL & OSU \\
\hline Air temperature $\left({ }^{\circ} \mathrm{C}\right)$ & $\begin{array}{l}\text { Increase everywhere } \\
\text { Range: }+2.0 \text { to }+4.0\end{array}$ & $\begin{array}{l}\text { Increase everywhere } \\
\text { Range: }+3.7 \text { to }+8.8\end{array}$ & $\begin{array}{l}\text { Increase everywhere } \\
\text { Range: }+3.7 \text { to }+4.7\end{array}$ \\
\hline Relative humidity $(\%)$ & $\begin{array}{l}\text { Increase everywhere } \\
\text { Range: }+4.0 \text { to }+22.0\end{array}$ & $\begin{array}{l}\text { Increase everywhere } \\
\text { Range: }+0.7 \text { to }+38.6\end{array}$ & $\begin{array}{l}\text { Increase everywhere } \\
\text { Range: }+2.9 \text { to }+16.4\end{array}$ \\
\hline Cloud cover $(\%)$ & $\begin{array}{l}\text { Increase in the low latitudes } \\
\text { of the west, high latitudes of } \\
\text { the mid-continent and mid- } \\
\text { dle and high latitudes of the } \\
\text { east; declines elsewhere. } \\
\text { Range: }-4.7 \text { to }+6.8\end{array}$ & $\begin{array}{l}\text { No change or increase } \\
\text { everywhere. } \\
\text { Range: } 0 \% \text { to }+18 \%\end{array}$ & $\begin{array}{l}\text { Declines west of } 85^{\circ} \text { lon- } \\
\text { gitude; increases elsewhere. } \\
\text { Range: }-9.9 \text { to }+5.2\end{array}$ \\
\hline Wind speed $\left(\mathrm{m} \mathrm{s}^{-1}\right)$ & $\begin{array}{l}\text { Decrease in the low latitudes } \\
\text { of the west; no change or } \\
\text { slight increase in the mid- } \\
\text { and high latitudes of the } \\
\text { west; no change to a slight. } \\
\text { decrease elsewhere. } \\
\text { Range: }-2.2 \text { to }+1.1\end{array}$ & $\begin{array}{l}\text { No change or increase } \\
\text { everywhere. } \\
\text { Range: } 0.0 \text { to }+2.4\end{array}$ & $\begin{array}{l}\text { Decrease in mid-latitudes; } \\
\text { no change to small increase } \\
\text { elsewhere. } \\
\text { Range: }-2.2 \text { to }+1.8\end{array}$ \\
\hline Short-wave radiation $\left(\mathrm{W} \mathrm{m}^{-2}\right)$ & $\begin{array}{l}\text { Slight increase in mid- } \\
\text { latitudes of the west; no } \\
\text { change or decrease else- } \\
\text { where. } \\
\text { Range: }-5.0 \text { to }+5.8\end{array}$ & $\begin{array}{l}\text { No change or increase } \\
\text { everywhere. } \\
\text { Range: } 0.0 \text { to }+29.5\end{array}$ & $\begin{array}{l}\text { Decrease east of } 85^{\circ} \text { lon- } \\
\text { gitude } \text { no change or in- } \\
\text { crease elsewhere. } \\
\text { Range: }-4.6 \text { to }+9.8\end{array}$ \\
\hline Total radiation $\left(\mathrm{W} \mathrm{m}^{-2}\right)$ & $\begin{array}{l}\text { Increase everywhere. } \\
\text { Range: }+14.7 \text { to }+38.6\end{array}$ & $\begin{array}{l}\text { Increase everywhere. } \\
\text { Range: }+28.1 \text { to }+80.0\end{array}$ & $\begin{array}{l}\text { Increase everywhere. } \\
\text { Range: }+16.0 \text { to }+40.0\end{array}$ \\
\hline Water temperature $\left({ }^{\circ} \mathrm{C}\right)$ & $\begin{array}{l}\text { Increase everywhere. } \\
\text { Range: }+0.6 \text { to }+7.5\end{array}$ & $\begin{array}{l}\text { Increase everywhere. } \\
\text { Range: }+2.6 \text { to }+7.6\end{array}$ & $\begin{array}{l}\text { No change or increase } \\
\text { everywhere. } \\
\text { Range: } 0.0 \text { to } 6.9\end{array}$ \\
\hline
\end{tabular}
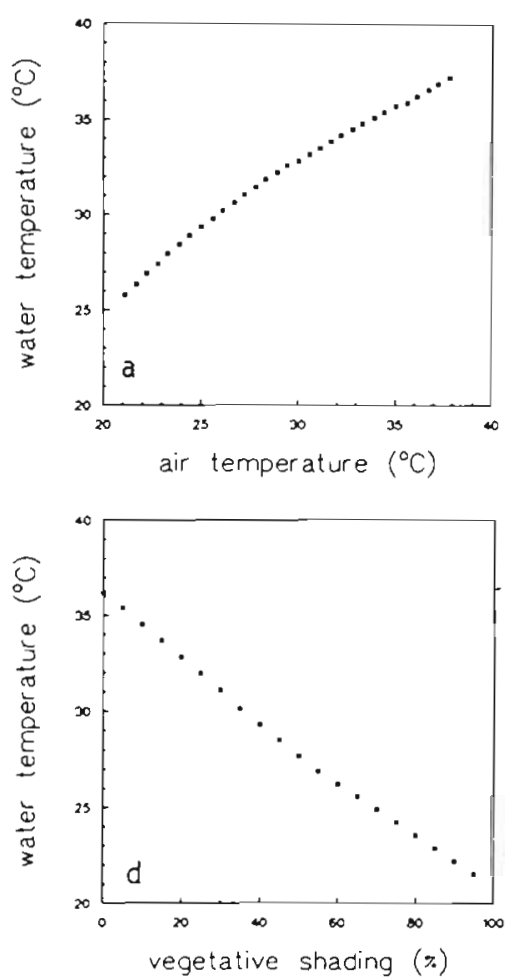
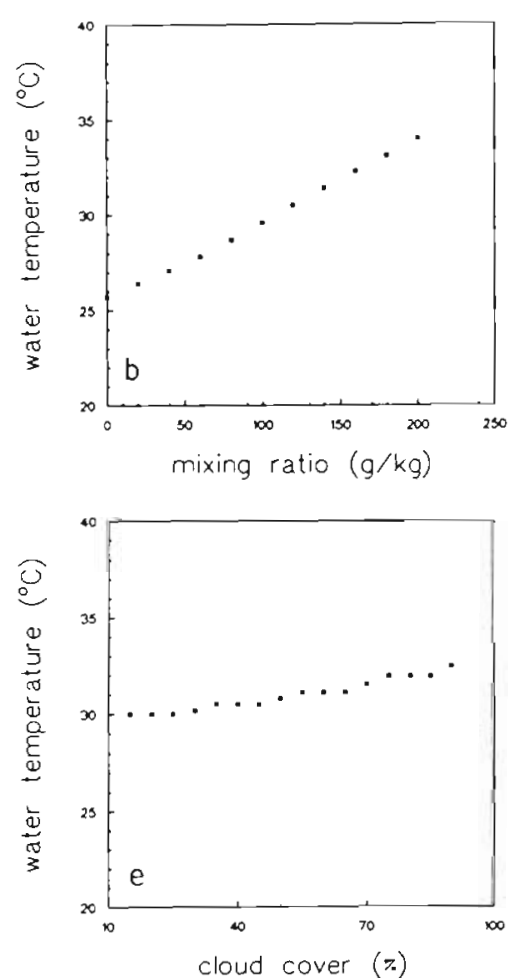

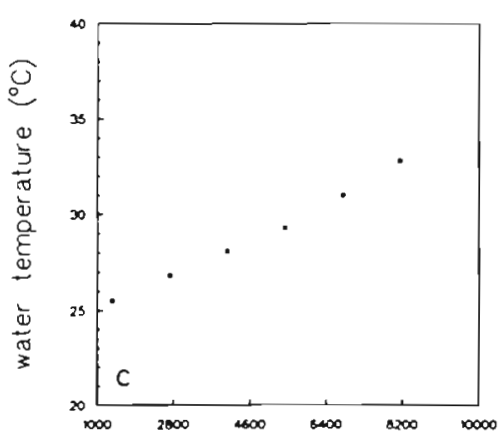

shortwave radiation ( $\mathrm{Kcal} / \mathrm{m}^{2} /$ day)

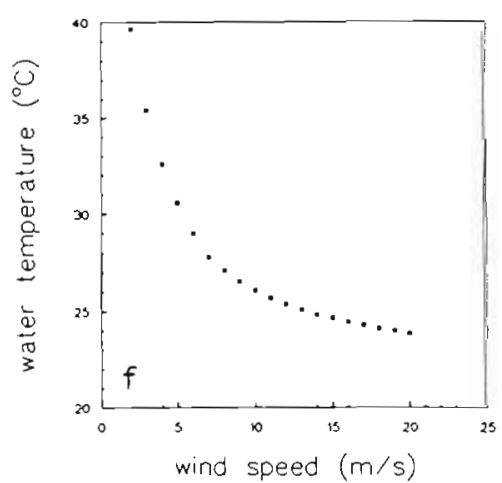

Fig. 5. Sensitivity of computed equilibrium water temperature to: (a) air temperature; (b) mixing ratio (humidity); (c) short-wave radiation; (d) vegetative shading; (e) cloud cover; and (f) wind speed 
Table 4. Waste load allocation characteristics for a sample stream in the southern USA

\begin{tabular}{|lcc|}
\hline & Effluent & Headwater \\
\hline Dissolved oxygen $\left(\mathrm{mg} \mathrm{l}^{-1}\right)$ & 5.0 & 7.0 \\
Flow $\left(\mathrm{m}^{3} \mathrm{~d}^{-1}\right)$ & $1.07 \times 10^{6}$ & $2.14 \times 10^{6}$ \\
BCD5 $\left(\mathrm{mg} \mathrm{l}^{1}\right)$ & 5.0 & 1.0 \\
Nitrate $\left(\mathrm{mg} \mathrm{l}^{-1}\right)$ & 2.0 & 0.1 \\
Stream length $=32.26 \mathrm{~km}$ & BCD decay rate $=1.252 \mathrm{~d}^{-1}$ \\
Velocity $=52.8 \mathrm{~km} \mathrm{~d}^{-1}$ & Reaeration rate $=5.943 \mathrm{~d}^{-1}$ \\
Stream DOstandard $=5 \mathrm{mg} \mathrm{l}^{-1}$ & Nitrification rate $=0.985 \mathrm{~d}^{-1}$ \\
DO saturation $=6.6 \mathrm{mg} \mathrm{l}^{-1}$ & BOD settling rate $=0.0 \mathrm{~d}$ \\
& \multicolumn{2}{l}{} \\
\hline
\end{tabular}

\section{DISCUSSION}

Fig. 6 summarizes the impact of water temperature on dissolved oxygen given the stream characteristics of Table 4 and a 'secondary' level of effluent treatment (which is the minimum level required for municipal dischargers under the Federal Clean Water Act). In Fig. 6, the dashed line shows the commonly encountered dissolved oxygen water quality standard of $5 \mathrm{mg} \mathrm{l}^{-1}$. DO levels fall below this values in all but the $25^{\circ} \mathrm{C}$ water temperature case. Fig. 4 suggests that mean diurnal water temperatures could exceed $25^{\circ} \mathrm{C}$ throughout the southern United States under all 3 GCM scenarios. This means that more stringent levels of waste water treatment ('advanced' treatment) are likely in order, at least during the summer season for stream and effluent discharge situations such as those described in Table 4.

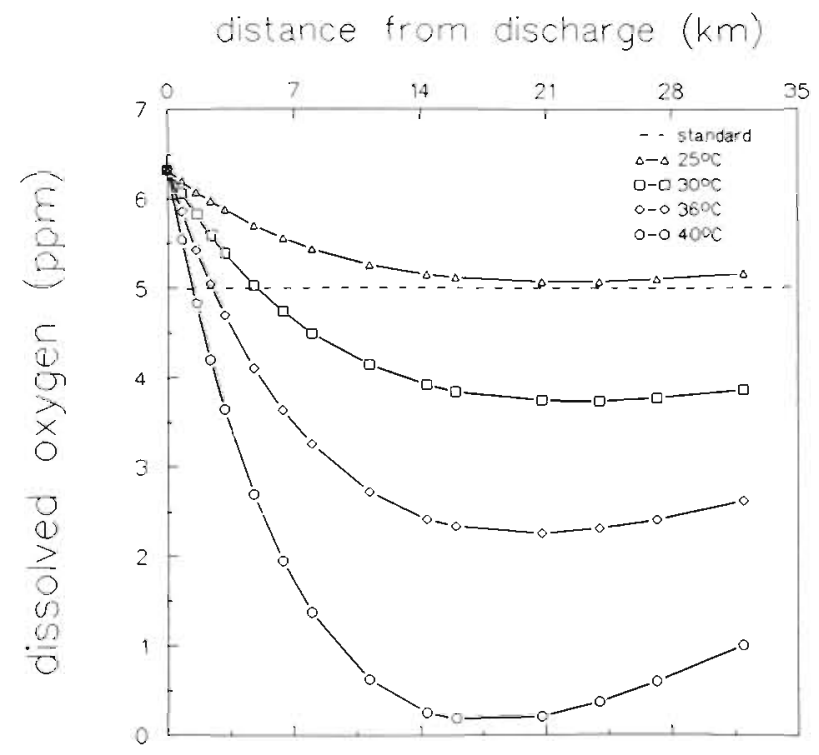

Fig. 6. Impact of water temperature on dissolved oxygen assuming a secondary level of water treatment
Since switching from 'secondary' to 'advanced' treatment involves a sizable reduction in the loadings of oxygen-demanding substances from an effluent, such a move to more stringent requirements could protect DO conditions for the hypothetical 'typical' stream under appreciably elevated water temperature regimes. The modeling results summarized in Fig. 7 illustrate that for mean daily water temperatures as high as $40^{\circ} \mathrm{C}$, advanced waste water treatment technology could maintain stream water at a DO close to the $5 \mathrm{mg} \mathrm{l}^{-1}$ standard as long as stream flow does not also decline. With no headwater flow (i.e. virtually all the water below the discharge point as effluent), however, even advanced treatment would lead to in-stream DO levels below the target of $5 \mathrm{mg} \mathrm{l}^{-1}$.

Giving detailed answers to the question of whether climate changes would eliminate the flow in streams that are presently perennial would be difficult to address with any precision given the lack of agreement among GCMs on precipitation estimates and associated changes in watershed hydrology. Still, the implication of the examples outlined above is that for streams with characteristics similar to those of Table 4, current treatment technology options are adequate to meet the DO demands of all GCM scenarios examined.

An alternative (or at least a supplement) to expensive advanced treatment facilities is to modify ambient stream temperatures. Although not practical on larger river systems, riparian vegetation may be a useful tool on smaller streams with widths around $15 \mathrm{~m}$. Riparian shading decreases water temperature through the blockage of short-wave radiation. Techniques based on a change in the $H_{r}$ term of Eq. (1) can model these

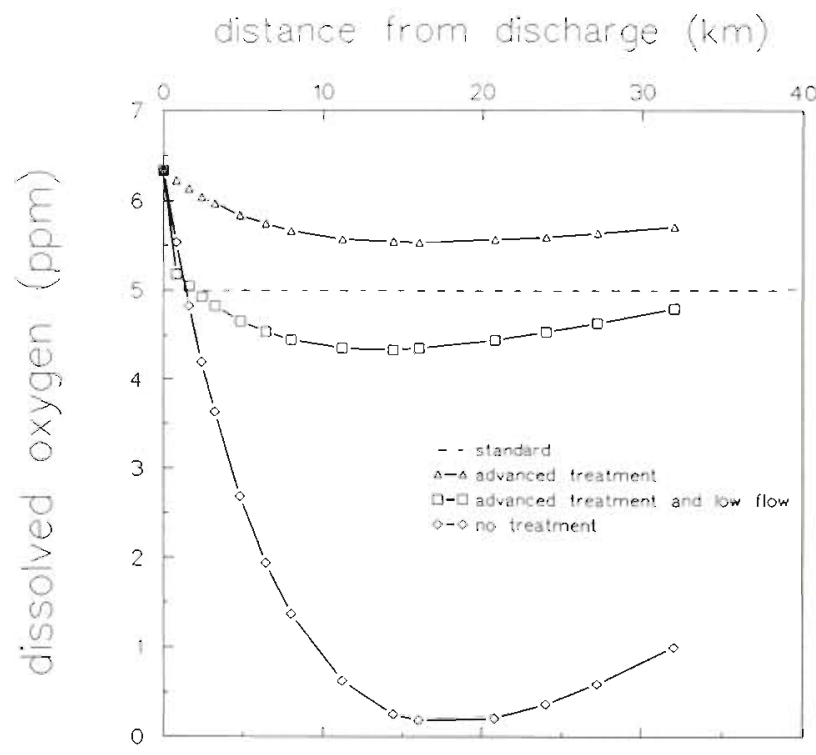

Fig. 7. Effect of treatment and flow on dissolved oxygen under elevated water temperatures $\left(40^{\circ} \mathrm{C}\right)$ 


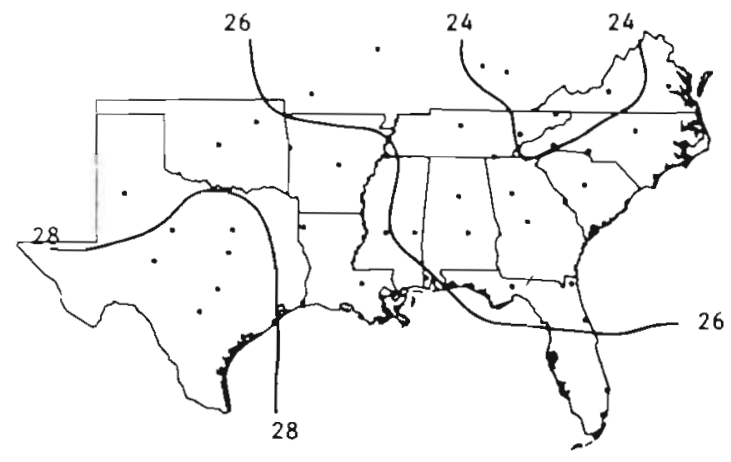

a

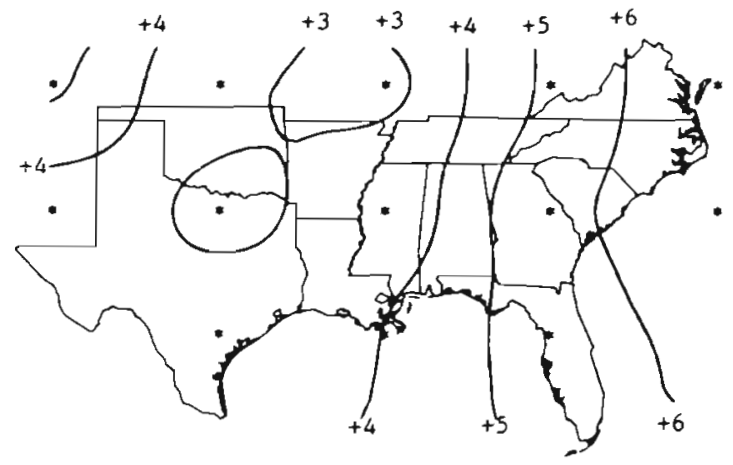

C

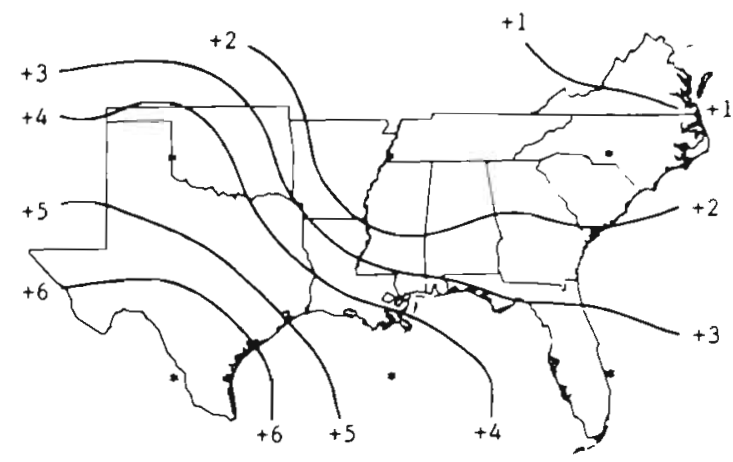

b

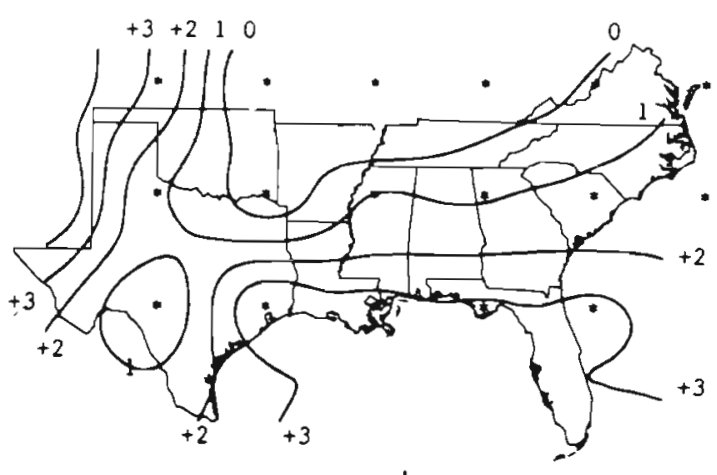

d

Fig. 8. Historical mean July equilibrium surface water temperatures and changes from computed GCM base water temperatures resulting from doubled atmospheric $\mathrm{CO}_{2}$ and postulated southern forest migration ( ${ }^{\circ} \mathrm{C}$ ). (a) Historical base; (b) GISS; (c) GFDL; (d) OSU

effects. Concomitant changes in humidity, cloud cover, wind speed and air pressure determine the impact of changes in $\mathrm{H}_{r}$ on the calculation of equilibrium temperature.

Climate change could also decrease the shading benefits. Should riparian tree cover decline, this would accentuate the impact of greenhouse effect increases in air temperatures since vegetative removal can increase radiation exposure 6 to 7 -fold (Brown 1970), with potential water temperature increases of more than $5{ }^{\circ} \mathrm{C}$ (US EPA 1973). Rising levels of $\mathrm{CO}_{2}$ are likely to alter growth and reproduction rates of trees by affecting biochemical processes like photosynthesis, respiration and water use efficiency. These features play an important role in determining the distribution of species and productivity of forests (Andrasko \& Wells 1989). Forest community composition would change as species more tolerant of environmental stress and variability supplant species unable to adapt to these alterations or that are at the edge of their present ranges.

Several recent studies serve to clarify these issues (Andrasko \& Wells 1989, Winjum \& Neilson 1989, Joyce et al. 1990). After a comparison of 2 studies, Joyce et al. (1990) conclude that some confidence may be placed in predictions of climate change induced changes in total biomass, but less on the structure and abundance of individual species. Andrasko \& Wells (1989) and Winjum \& Neilson (1989), on the other hand, conclude that the southern ranges of many eastern U.S. forest species might shift northward 200 to $1000 \mathrm{~km}$. To simulate this forest scenario, the species of Table 2, initially assumed to occur only south of latitude $34^{\circ}$, are assumed throughout the study area east of longitude $97^{\circ} \mathrm{W}$ No hypothesis of changing species productivity is made. Since only riparian species are included in this example, projected changes in non-riparian or upland tree species are not considered. West of longitude $97^{\circ} \mathrm{W}$, where larger tree species are even now under considerable climatic stress, forest composition is held constant. Fig. 8 shows these vegetatively modified model results.

The information in Fig. 8 suggests that under the GISS and OSU scenarios, the primary control on increases in water temperature east of longitude $97^{\circ} \mathrm{W}$ is total radiation. By increasing the shading coefficient, the amount of short-wave radiation reaching the water surface decreases and the range of increases in water temperature declines to $\mathrm{ca} 1{ }^{\circ} \mathrm{C}$. The secondary GISS scenario area of maximum temperature increase in the 
southwest does not change. The GFDL scenario remains largely unchanged under the case of vegetative migration. Water temperature increases are only slightly smaller than under the original doubled atmospheric $\mathrm{CO}_{2}$ example. This implies a source other than short-wave radiation, e.g. air temperature, estimated long-wave radiation (a function of air temperature and percent cloud cover) or humidity, must drive the GFDL water temperature increases.

The preceding discussion has focused on the eastern and central portions of the southern United States (i.e. the southeastern United States) where substantial levels of riparian corridor shading exist under current conditions and are quite probable under future climate change scenarios. In the more westward portions of the study area, mature tree species in excess of $18 \mathrm{~m}$ become much less common. From the information in Fig. 3, it can be seen that as the height of near-bank vegetation declines, so does the width of the streams protected. This suggests that the benefits of riparian corridor shading would be of considerable importance eastward of around $97^{\circ} \mathrm{W}$ longitude, but that the drier western regions will need other options.

\section{SUMMARY}

Because of uncertainties in the scenarios produced by GCMs, many water managers have been hesitant to make use of regional greenhouse projections. Although such uncertainties may be important for studies requiring detailed precipitation or flow inputs, analyses based on the more stable GCM temperature estimates can still address many crucial water quality issues. Regional patterns of surface water temperature estimated via GCM outputs have been established. Examination of several such scenarios shows surface water temperatures increasing up to $7^{\circ} \mathrm{C}$ throughout the southern United States. Two of the 3 models project an area of maximum temperature increase in the northeastern quadrant of the study area. A Streeter-Phelps waste load allocation model was then applied as a regional screening tool under the GCM scenarios. Although existing advanced treatment technology would be sufficient to maintain desirable levels of instream DO, the use of such technology will be necessary on a much wider scale.

The use of extensive riparian vegetation shading could help to supplement advanced water treatment technology. The nomogram in fig. 3 relates vegetative height to shading coefficient. Recent findings from forest ecologists working in the area of forest response to global warming suggest likely changes in riparian ecosystems of the southern United States, which were then included in the regional water temperature model.
Results suggest that under 2 of the 3 scenarios, projected levels of riparian vegetation shading could appreciably offset the potential water temperature increases east of longitude $97^{\circ} \mathrm{W}$. No firm hypothesis on changes west of $97^{\circ} \mathrm{W}$ longitude was available. If present maximum levels of natural riparian assemblages continue but no species migration were to take place, water temperatures could still rise in some areas by as much as $7^{\circ} \mathrm{C}$. If other environmental or anthropogenic stresses were to result in a major decrease in vegetative cover, such water temperature increases could easily occur. Water temperature changes of this extreme would then likely lead to major degradation in water quality conditions along appreciable reaches of streams receiving oxygen-demanding point source discharges.

\section{LITERATURE CITED}

American Public Health Association (1985). Standard methods, 16th edn. American Public Health Association, Washington, D.C., pp. 413-414

Andrasko, K., Wells, J. B. (1989). North American forests during rapid climate change: overview of effects and policy response options. In: Proceedings of the Second North American Conference on Preparing for Climate Change. Climate Institute, Washington, D.C., p. 282-291

Brown, G. W. (1970). Predicting the effect of clearcutting on stream temperature. Journal of Soil and Water Conservation 25: 11-13

Cooter, E. J. (1990). The impact of climate change on continuous corn production in the southern USA. Climatic Change 16: $53-82$

Edinger, J., Geyer, J. (1965). Heat exchange in the environment, John Hopkins University

Geraghty, J. J., Miller, D. W., Van der Leeden, F., Troise, F. L. (1973). Water Atlas of the United States. Water Information Center, Port Washington, New York, Plate 10

Grotch, S. L. (1988). Regional inter-comparisons of general circulation model predictions and historical climate data. TR041, DOE/NBB-0084, National Technical Information Service, Springfield, Virginia

Hansen, J., Jacies, A., Rind, D., Russell, G., Stone, P., Fung, I., Ruedy, R., Lerner, J. (1984). Climate sensitivity: analysis of feedback mechanisms. In: Hansen, J. E., Takahashi, T. (eds.) Climate processes and climate sensitivity (Maurice Ewing Series, No.5). American Geophysical Union, Washington, D.C.

Jacoby, H. (1989). Likely effects of climate on water quality. In: Proceedings of the Second North American Conference on Preparing for Climate Change. Climate Institute, Washington, D.C., p. 348-352

Joyce, L. A., Fosberg, M. A., Comanor, J. M. (1990). Climate change and America's Forests. General Technical Report RM-187, U.S. Dept. Agriculture Forest Service, Rocky Mountain Forest and Range Experiment Station, Ft. Collins, Colorado

Katz, R. W., Brown, B. G. (1989). Climate change for extreme events: an application of the theory of extreme values. In: Preprints of the 11 th Conference on Probability and Statistics in Atmospheric Sciences, October 1-5, Monterey, Calif., AMS, Boston, Mass., p. 10-13

Knapp, C. L., Stoffel, T. L., Whitaker, S. D. (1980). Insolation 
data manual. SERI/SP-755-789, Solar Energy Information Data Bank, Solar Energy Research Institute, Golden, Col.

Leo, W. M., Thomann, R. V., Gallagher, T. W (1984). Before and after case studies: comparisons of water quality following municipal treatment plant improvements. 430/9007, U.S. Environmental Protection Agency, Office of Water Program Operations, Washington, D.C.

Manabe, S., Wetherald, R. T. (1987). Large scale changes of soil wetness induced by an increase in atmospheric carbon dioxide. J. Atmos. Sciences 44: 1211-1235

Mearns, L. O., Katz, R. W., Schneider, S. H. (1984). Extremehigh temperature events: changes in their probabilities with changes in mean temperature. J. Climate appl. Meteor. 23: 1601-1614

Miller, B. A., Brock, W. G. (1989). Global climate change implications for the Tennessee Valley Authority Reservoir System. In: Proceedings of the Second North American Conference on Preparing for Climate Change. Climate Institute, Washington, D.C., p. 493-500

Mills, W. B, Dean, J. D., Porcella, D. B., Gherini, S. A., Hudson, R. J. M., Frick, W. E., Rupp, G. L., Bowie, G. L. (1982). Water quality assessment: a screening procedure for toxic and conventional pollutants. Part 1. EPA-600/682-004a, U.S. Environmental Protection Agency, Athens, $\mathrm{Ga}$, p. 423-445

National Oceanic and Atmospheric Administration (NOAA), (1978). Climatography of the United States, No. 60 NOAA/ EDS/NCDC, Asheville, N. Carol

O'Connor, D. J. (1984). Waste load allocation seminar notes. U.S. Environmental Protection Agency, Washington, D.C.

Oklahoma State Department of Agriculture (1981). Forest

Editor: Professor V. Meentemeyer trees of Oklahoma. Publ. INo. 1, Rev. edn No. 12 Oklahoma Forestry Division. State Department of Agriculture, Oklahoma City, Okl.

Schlesinger, M. E., Zong-Ci Zhao (1989). Seasonal climatic changes induced by doubled $\mathrm{CO}_{2}$ as simulated by the OSU Atmospheric GCM/Mixed-Layer Ocean Model. J. Climate 2 (5): 459-495

US Environmental Protection Agency (EPA) (1973). Methods for identifying and evaluating the nature and extent of non-point sources of pollutants. EPA-430/9-73-014, U.S Government Printing Office, Washington, D.C., p. 1-114

US Environmental Protection Agency (EPA) (1976). Quality criteria for water. EPA-440/9-76-023, U.S., Washington, D.C.

US Environmental Protection Agency (EPA) (1986). Quality criteria for water. EPA-440/5-86-001, Office of Water Regulations and Standards, Washington, D.C.

US Environmental Protection Agency (EPA) (1989). EPA Journal 15 (1): $1-52$

Waggoner, P. (ed.) (1990). Climate change and U.S. Water Resources. John Wiley \& Sons, New York

Wetland Training Institute, Inc. (1989). Field guide for delineating wetlants: unified federal method. WTI 89-1, Wetland Training Institute, Inc., Poolesville

Winjum, J. K., Neilson, R. P. (1989). How it might be: forests EPA Journal 15 (1): 11-13

Zison, S. W. Mills, W. B., Deimer, D., Chen, C. W. (1978), Rates, constants, kinetics formulations in surface water quality modeling. Prepared for the Environmental Research Laboratory, US Environmental Protectional Agency, Athens, Ga

Manuscript first received: January 5, 1990

Revised version accepted: July 24,1990 